\title{
HLA-alleles class I and II associated with genetic susceptibility to neuromyelitis optica in Brazilian patients
}

\author{
Alelos HLA classes I e II associados à suscetibilidade genética a neuromielite óptica em \\ pacientes brasileiros
}

Cláudia Suemi Kamoi KAY', Rosana Herminia SCOLA, Raquel Cristina ARNDT1', Paulo José

LORENZONI', Lineu Cesar WERNECK'

\begin{abstract}
Objective: To study the genetic susceptibility to neuromyelitis optica (NMO) as well as the relationship between HLA genotypes and susceptibility to the disease in the southern Brazilian population. Methods: We analyzed patients with NMO, who met criteria for Wingerchuk's diagnosis of NMO, with detected serum anti-AQP4-IgG antibody. The HLA genotyping was performed by high-resolution techniques (Sanger sequencing) in patients and controls. The HLA genotypes were statistically compared with a paired control population. Results: The HLA genotyping revealed the diversity of the southern Brazilian population whose HLA profile resembled European and Asian populations. Some alleles had statistical correlations with a positive association (increased susceptibility) with NMO, particularly the HLA-DRB1*04:05 and *16:02. Conclusions: In our study, the HLA genotype was different to that previously reported for other Brazilian populations. Although our study had a small cohort, HLA genotypes were associated with increased susceptibility to NMO for HLA-DRB1*04:05 and *16:02. The alleles of HLA class I HLA-A*02:08 and *30:09, HLA-B*08:04 and *35:04 showed an association before the Bonferroni correction.
\end{abstract}

Keywords: Genetic predisposition to disease; HLA antigens; immunogenetics; major histocompatibility complex; neuromyelitis optica.

\section{RESUMO}

Objetivo: Estudar a suscetibilidade genética a neuromielite óptica (NMO) assim como sua relação com o genótipo HLA na população do sul do Brasil. Métodos: Nós analisamos pacientes com NMO que preenchiam os critérios diagnósticos de Wingerchuk para NMO, com presença do anticorpo anti-AQP4-IgG no soro. O genótipo HLA foi realizado usando técnicas de alta resolução (sequenciamento de Sanger) em pacientes e controles. Genótipos HLA foram estatisticamente comparados com uma população controle pareada. Resultados: Genotipagem HLA revelou a diversidade da população sul brasileira cujo perfil HLA lembra as populações europeia e asiática. Alguns alelos tiveram correlação estatística com associação positiva (suscetibilidade aumentada) com NMO, particularmente o HLA-DRB1*04:05 e *16:02. Conclusões: Em nosso estudo, o genótipo HLA foi diferente do previamente relatado em outras populações brasileiras. Embora o número de pacientes tenha sido pequeno, HLA específicos foram associados com suscetibilidade aumentada a NMO para HLA-DRB1*04:05, *16:02. Os alelos HLA classe I HLA*02:08 e *30:09, HLA-B*08:04 e *35:04 tiveram associação antes da correção de Bonferroni.

Palavras-chave: Predisposição genética para doença; antígenos HLA; imunogenética; complexo principal de histocompatibilidade; neuromielite óptica.

Neuromyelitis optica (NMO) is an inflammatory disease of the central nervous system that has been considered a "channelopathy", primarily following the description of a specific IgG antibody against the aquaporin-4 channel(AQP4)1. In addition,

\footnotetext{
'Universidade Federal do Paraná, Hospital de Clínicas, Departamento de Clínica Médica, Serviço de Neurologia, Curitiba PR, Brasil.

Cláudia Suemi Kamoi Kay (iD https://orcid.org/0000-0003-0173-0809; Rosana Herminia Scola (iD) https://orcid.org/0000-0002-3957-5317; Raquel Cristina Arndt (iD https://orcid.org/0000-0002-3745-7595; Paulo José Lorenzoni (iD https://orcid.org/0000-0002-4457-7771; Lineu Cesar Werneck https://orcid.org/0000-0003-1921-1038

Correspondence: Lineu Cesar Werneck; Hospital de Clínicas; Rua General Carneiro, 181, $3^{\circ}$ andar, sala 310; 80060-900 Curitiba PR, Brasil; E-mail: Lineu. werneck@hc.ufpr.br

Conflict of interest: Cláudia Suemi Kamoi Kay:Travel grants to attend meetings from Novartis, Genzyme-Sanofi and Roche; Rosana Herminia Scola: Travel grants to attend meetings from Bayer-Schering, Merck-Serono, TEVA, Abbott-Biogen, Novartis and Genzyme; Conference fees from Merck-Serono, Novartis and Genzyme; Raquel Cristina Arndt:There is no conflict of interest to declare; Paulo José Lorenzoni: There is no conflict of interest to declare; Lineu Cesar Werneck: Conference fees from Merck-Serono, Bayer-Schering, Abbott-Biogen, Roche, TRB Pharma and Boehringer-Ingelheim; Travel grants to attend meetings from Bayer-Schering, Merck-Serono, TEVA, Abbott-Biogen, TRB Pharma, Genzyme; Fees for clinical trials from TRB Pharma, Bayer-Schering, Abbott; Research grants from the Conselho Nacional de Pesquisas (CNPq), Fundação Araucária, NIH (Bethesda), Merck-Serono, Biogen; Productivity grants from CNPq 1A (PQ1A), Universidade Federal do Paraná (Senior Professor).

Received 25 October 2018; Accepted 08 January 2019.
} 
the term "astrocytopathy" has been proposed because histopathological studies have shown that astrocyte injury is the primary event, which occurs in the active lesions of $\mathrm{NMO}^{2,3}$.

The major histocompatibility complexes are very dense and contain a polymorphic genomic region that expresses the human leukocyte antigen (HLA) present in the membrane of the T-cell receptors. Their high polymorphisms are due to variation in the extracellular domains forming the walls of the cleft where the peptides bind ${ }^{4}$. The HLA class II alleles are more frequently studied, but class I alleles are involved in the presentation of endogenous antigens and in the inhibition of natural killer cells, which could play a role in autoimmune diseases ${ }^{5}$.

Although the HLA system has been studied in multiple sclerosis since the early 1970s, few studies have described the HLA system in $\mathrm{NMO}^{6,7,8,9,10,11,12,13,14,15,16,17,18,19,20,21,22}$. Several studies have associated specific HLA class II alleles with susceptibility to $\mathrm{NMO}^{8,9,10,11,12,13,14,15,16,17,18,19,20,21,22,23}$. Recent studies have shown a relationship between NMO and HLA class II, particularly for the $D P B 1^{*} 05: 01, D R B 1^{*} 03$ and $D R B 1 * 16: 02$ alleles $7,8,9,10,11,12,13,14,15,16,17,18,19,20,21,22$. However, HLA class I alleles have only rarely been studied in $\mathrm{NMO}^{10}$.

In Brazilian NMO patients, to the best of our knowledge, only three studies in Brazil have analyzed HLA class II alleles, and HLA class I alleles have not yet been studied ${ }^{10,11,12,21}$. In addition, no study has been done in NMO patients from a southern Brazilian population that has a large proportion of individuals descended from Europeans.

In this study, we analyzed HLA class I and II profiles, with genotyping by high resolution techniques, among patients with NMO, born and raised in southern Brazil, to identify whether there is a relationship between the HLA genotype and susceptibility to NMO in the southern Brazilian population.

\section{METHODS}

\section{Patients}

We analyzed 768 patients with demyelinating disorders admitted from 2000 to 2018 at the outpatient clinic of the Hospital de Clínicas of Universidade Federal do Paraná (Curitiba, Brazil). Neuromyelitis optica was identified according Wingerchuk's diagnostic criteria ${ }^{24,25,26,27}$. Neuromyelitis optica was defined by positive anti-AQP4-IgG antibody serum status and the presence of at least one of the following: 1) single, recurrent or simultaneous bilateral optic neuritis; 2) longitudinally extensive transverse myelitis ( $\geq 3$ vertebral segments); or 3) recurrent brainstem, hypothalamic or cerebral symptoms ${ }^{24,25,26}$. We found 23 patients with NMO. We excluded five patients with negative AQP4-IgG serum status and three patients who were not born in the southern region of Brazil. Thus, we included 15 patients who fulfilled the criteria for NMO with positive AQP4-IgG serum status. We classified patients based on skin color. Female gender and white skin color were predominant in our sample. The age of onset had a median of 37 (range 24-63) years, the Expanded Disability Status Scale median was 6.0 (range 2.5-8.5) (Table 1). The indirect immunofluorescence technique was used for AQP4-IgG detection in all patient samples. Other serum antibodies were detected in 13 patients (Table 1). Other concomitant diseases included autoimmune disease in four patients and two with neoplasm (breast or lung) after the diagnosis of NMO (Table 1). Brain magnetic

Table 1. Clinical, laboratory and radiological findings of NMO patients from southern Brazil.

\begin{tabular}{|c|c|}
\hline Variable & Number (\%) \\
\hline \multicolumn{2}{|l|}{ Gender } \\
\hline Female & $14(93.3 \%)$ \\
\hline Male & $1(6.7 \%)$ \\
\hline \multicolumn{2}{|l|}{ Skin color } \\
\hline White & $12(80.0 \%)$ \\
\hline Brown (mulatto) & $3(20.0 \%)$ \\
\hline Age at onset (median in years) & 37 (range 24-63) \\
\hline EDSS score (median) & $6.0(2.5-8.5)$ \\
\hline \multicolumn{2}{|l|}{ Clinical presentation } \\
\hline Optic neuritis and myelitis & $13(86.6 \%)$ \\
\hline Optic neuritis & $1(6.7 \%)$ \\
\hline Longitudinal extensive myelitis transverse & $1(6.7 \%)$ \\
\hline \multicolumn{2}{|l|}{ Abnormal laboratory findings } \\
\hline Anti-AQP4-IgG antibody & $15(100 \%)$ \\
\hline Antinuclear antibody & $6(40.0 \%)$ \\
\hline Thyroid peroxidase antibody & $2(13.3 \%)$ \\
\hline Thyroglobulin antibody & $3(20.0 \%)$ \\
\hline Antiphospholipid antibody & $4(26.6 \%)$ \\
\hline Antimitochondrial antibody & $1(6.7 \%)$ \\
\hline Antiendomysial antibody & $1(6.7 \%)$ \\
\hline \multicolumn{2}{|l|}{ Associated autoimmune Disorders } \\
\hline Hypothyroidism & $3(20.0 \%)$ \\
\hline Antiphospholipid syndrome & $1(6.7 \%)$ \\
\hline \multicolumn{2}{|l|}{ Associated cancer } \\
\hline Breast cancer & $1(6.7 \%)$ \\
\hline Bronchoalveolar (lung) cancer & $1(6.7 \%)$ \\
\hline \multicolumn{2}{|l|}{ Brain MRI findings } \\
\hline Normal & $9(60 \%)$ \\
\hline Abnormal unspecific abnormality & $4(26.6 \%)$ \\
\hline "multiple sclerosis" radiological criteria & $2(13.3 \%)$ \\
\hline \multicolumn{2}{|l|}{ Cervical MRI findings } \\
\hline Longitudinally extensive myelitis & $14(93.3 \%)$ \\
\hline Normal & $1(6.7 \%)$ \\
\hline
\end{tabular}

Expanded Disability Status Scale 
resonance imaging was normal in nine patients and abnormal in six patients, and cervical magnetic resonance imaging showed longitudinally extensive transverse myelitis in all patients except one (Table 1).

\section{Controls}

The control group comprised 606 healthy donors of bone marrow transplant from our hospital. Only individuals who were born and raised in the southern regions of Brazil, mostly in the Paraná State, were selected. All were over 30 years old and were unrelated. The number of individuals in each division of the control group was calculated separately for each HLA gene, based on the number of alleles studied in the disease groups. These control groups were also statistically paired by skin color. The control groups had 384 alleles of $H L A-A, 462$ alleles of $H L A-B, 138$ alleles of $H L A-C, 68$ alleles of $H L A-D P B 1,300$ alleles of $H L A-D Q B 1$ and 504 alleles of $H L A-D R B 1$ that were detected by high resolution genotyping. The remaining alleles presented with ambiguity and were not assessed.

\section{Genotyping}

Genomic DNA was isolated from peripheral blood using a standard phenol-chloroform technique. We used Sanger sequencing to analyze HLA class I and II. Conventional polymerase chain reaction was used to amplify the $H L A-A$ gene (exons 2, 3 and 4); $H L A-B$ gene (exons 2, 3 and 4); $H L A-C$ gene (exons 2, 3 and 4); HLA-DPB1 gene (exons 2, 3 and 4); $H L A-$ $D R B 1$ gene (exon 2); and $H L A-D Q B 1$ gene (exons 2 and 3). These exons encode the extracellular domains responsible for the peptide-binding grooves of HLA molecules ${ }^{4}$. These amplified fragments were directly sequenced in the forward direction using an ABI 3130 Avant Genetic Analyzer (Hitachi High-Technologies Corporation, Tokyo, Japan). The sequences were compared by application-specific software (Assign SBT, Conexio-Genomics, Fremantle, Australia and HLA SBT U-Type 6.0 RUO by Life Technologies) to define the HLA class I and II alleles. The allelic frequencies were reported using a high-resolution level. The ambiguous HLA genotypes were not suitable for statistical analysis and excluded from each allele group.

\section{Data analysis}

Data were analyzed using SPSS statistics, version 19. The allelic frequencies, including homozygotes and heterozygotes of the HLA class I and class II, were compared using the chi-squared test with Yates' continuity correction. In all assays, statistical significance was determined at $\mathrm{p}<0.05$. These values were corrected by the Bonferroni method according to the number of alleles analyzed. The odds ratio (OR) was calculated and 95\% confidence intervals (CI) were used to describe the strength of association between data.

\section{Standard protocol approvals}

This study was approved by the Ethical Committee for Research on Humans of the Hospital de Clínicas, Universidade Federal do Paraná, and was conducted after obtaining patient consent.

\section{RESULTS}

\section{HLA class I}

Of the 15 patients analyzed, nine showed ambiguous results for $H L A-A$ alleles; six showed ambiguous results for $H L A-B$ alleles and seven patients showed ambiguous results for $H L A-C$ alleles. These patients were excluded.

\section{HLA-A alleles}

The most frequent alleles in the NMO group and the control group were *02:01 and *24:02. Alleles *02:08 and *30:09 did not occur in the controls and the difference in that frequency was statistically significant, which became non-significant after the Bonferroni correction (Table 2).

Table 2. Frequency of HLA class I A alleles in NMOSD patients from southern Brazil.

\begin{tabular}{|c|c|c|c|c|c|}
\hline \multirow[b]{2}{*}{ Variable } & NMOSD & Controls & \multirow[b]{2}{*}{$\mathrm{p}$-value } & \multirow[b]{2}{*}{ OR $(95 \% \mathrm{Cl})$} & \multirow[b]{2}{*}{$\mathrm{p}^{\mathrm{c}}$} \\
\hline & $\begin{array}{c}6 \text { patients, } 12 \text { alleles } \\
\mathrm{n}(\%)\end{array}$ & $\begin{array}{c}192 \text { individuals, } 384 \\
\text { alleles n (\%) }\end{array}$ & & & \\
\hline \multicolumn{6}{|l|}{ HLA-A } \\
\hline$\star 02: 01$ & $2(16.6)$ & $79(20.5)$ & 1.000 & $0.77(0.17-3.66)$ & NS \\
\hline *24:02 & $2(16.6)$ & $38(9.9)$ & 0.3463 & $1.82(0.38-8.62)$ & NS \\
\hline$\star 02: 08$ & $1(8.3)$ & 0 & 0.0061 & & NS \\
\hline$\star 30: 09$ & $1(8.3)$ & 0 & 0.0061 & & NS \\
\hline \multicolumn{6}{|l|}{ Others } \\
\hline Both groups \# & $6(66.4)$ & $140(36.2)$ & NS $\S$ & & NS \\
\hline Control group † & 0 & $127(33.4)$ & & & \\
\hline
\end{tabular}

HLA: human leukocyte antigen; NMOSD: neuromyelitis optica spectrum disorders; p-value: value of p using the chi-squared test with Yates' continuity correction; OR: odds ratio; $p^{c}$ : Probability after Bonferroni correction for 10 multiple comparisons for $p<0.05$; NS: Non-significant. \#: At least one allele was found in both groups: *01:01, *03:01, *24:03, *26:01, *66:01, *80:01; † Alleles found only in controls (one or more), *01:02, *01:03, *02:02, *02:04, *02:05, *02:11, *02:20,

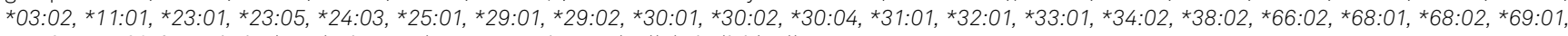
$\star 74: 01, * 74: 03$. §: statistical analysis was done comparing each allele individually. 


\section{HLA-B alleles}

The most frequent was *07:02, which was also frequent in the controls. Alleles *08:04 and *35:04 did not appear in the controls and the difference in that frequency was statistically significant, which became non-significant after the Bonferroni correction (Table 3).

\section{HLA-C alleles}

Allele *04:01 was the most frequent in the NMO group and the control group. Allele *15:02 was rare in the controls and the difference in that frequency was statistically significant ( $p=0.0287$, OR 19.6 95\% CI 1.67-229.70). The difference in frequency of alleles lost their significance after the Bonferroni correction (Table 4).

\section{HLA class II}

Of the 15 patients analyzed, three showed ambiguous results for $H L A-D P B 1$ and for $H L A-D Q B 1$. These patients were excluded.

\section{HLA-DPB1 alleles}

The most frequent alleles were DPB1*04:02 and "04:01, which were also frequent in the controls. The alleles $D P B 1 * 17: 01$ and *16:01, despite the increased OR, were not significant. The other alleles were not statistically significant when compared with the control group (Table 5).

\section{HLA-DQB1 alleles}

The most frequent alleles were $D Q B 1 * 05: 01$ and *02:01, which were also frequent in the controls. The difference in frequency of other alleles were not statistically significant when compared with the control group (Table 6).

\section{HLA-DRB1 alleles}

The most frequent alleles were $D R B 1 * 03: 01$, "04:05, *10:01 and "16:02. Compared with the control group, these differences in frequency were statistically significant for "04:05 ( $p$ < 0.0001; OR 27.89; 95\% CI 4.47-173.97) and "16:02

Table 3. Frequency of HLA class I B alleles in NMOSD patients from southern Brazil.

\begin{tabular}{|c|c|c|c|c|c|}
\hline \multirow[b]{2}{*}{ Variable } & NMOSD & Controls & \multirow[b]{2}{*}{$p$-value } & OR & \multirow[b]{2}{*}{$\mathrm{p}^{\mathrm{c}}$} \\
\hline & $\begin{array}{c}9 \text { patients, } 18 \text { alleles } \\
n(\%)\end{array}$ & $\begin{array}{c}231 \text { individuals, } 462 \\
\text { alleles } n(\%)\end{array}$ & & $(95 \% \mathrm{Cl})$ & \\
\hline \multicolumn{6}{|l|}{ HLA-B } \\
\hline *07:02 & $3(16.7)$ & $31(6.7)$ & 0.2513 & $2.78(0.76-10.12)$ & NS \\
\hline *08:04 & $1(5.6)$ & 0 & 0.0148 & & NS \\
\hline *35:04 & $1(5.6)$ & 0 & 0.0148 & & NS \\
\hline \multicolumn{6}{|l|}{ Others } \\
\hline Both groups \# & $13(27.9)$ & $125(27.2)$ & $N S \S$ & & NS \\
\hline Control group † & 0 & 306 (66.1) & & & \\
\hline \multicolumn{6}{|c|}{ 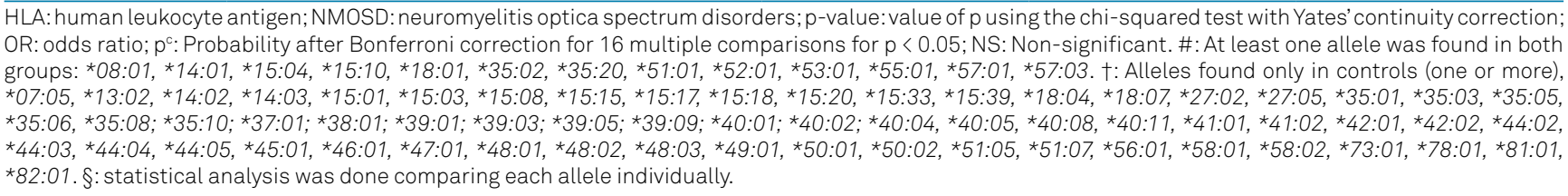 } \\
\hline
\end{tabular}

Table 4. Frequency of HLA class I C alleles in NMOSD patients from southern Brazil.

\begin{tabular}{|c|c|c|c|c|c|}
\hline \multirow[b]{2}{*}{ Variable } & NMOSD & Controls & \multirow[b]{2}{*}{$\mathrm{p}$-value } & \multirow[b]{2}{*}{ OR (95\% Cl) } & \multirow[b]{2}{*}{$\mathrm{p}^{\mathrm{c}}$} \\
\hline & $\begin{array}{c}8 \text { patients, } 16 \text { alleles } \\
n(\%)\end{array}$ & $\begin{array}{l}69 \text { individuals, } 138 \\
\text { alleles } n(\%)\end{array}$ & & & \\
\hline \multicolumn{6}{|l|}{ HLAC } \\
\hline *04:01 & $3(18.7)$ & $20(14.5)$ & 0.9348 & $1.36(0.36-5.21)$ & NS \\
\hline *15:02 & $2(12.5)$ & $1(0.7)$ & 0.0232 & $19.6(1.67-229.70)$ & NS \\
\hline *06:02 & $2(12.5)$ & $14(10.1)$ & 0.7701 & $1.26(0.26-6.15)$ & NS \\
\hline \multicolumn{6}{|l|}{ Others } \\
\hline Both groups \# & $9(56.3)$ & $63(45.6)$ & NS $\S$ & & NS \\
\hline Control group † & 0 & $40(29.1)$ & & & \\
\hline
\end{tabular}

HLA: human leukocyte antigen; NMOSD: neuromyelitis optica spectrum disorders; $p$-value: value of $p$ using the chi-squared test with Yates' continuity correction; OR: odds ratio; $p^{c}$ : Probability after Bonferroni correction for 12 multiple comparisons for $p$ < 0.05; NS: Non-significant; \#: At least one allele was found in both groups: *03:01, ${ }^{\star} 03: 03,{ }^{\star} 03: 04,{ }^{\star} 04: 07,{ }^{\star} 07: 02,{ }^{\star} 08: 02,{ }^{\star} 14: 02 ; \dagger:$ Alleles found only in controls (one or more), ${ }^{\star} 01: 02,{ }^{\star} 02: 02,{ }^{\star} 02: 10$, *03:02, *04:02, *05:01, *06:01, *06:05, *07:01, *07:04, *07:06, *12:01, *12:02, 12:03, *13:01, *15:05, *16:01, *16:02, *17:01; §: statistical analysis was done comparing each allele individually. 
Table 5. Frequency of HLA class II DPB1 in NMOSD patients and healthy controls from southern Brazil.

\begin{tabular}{|c|c|c|c|c|c|}
\hline \multirow[b]{2}{*}{ Variable } & NMOSD & Controls & \multirow[b]{2}{*}{$p$-value } & \multirow[b]{2}{*}{ OR (95\% Cl) } & \multirow[b]{2}{*}{$\mathrm{p}^{\mathrm{c}}$} \\
\hline & $\begin{array}{l}12 \text { patients, } 24 \\
\text { alleles } \mathrm{n}(\%)\end{array}$ & $\begin{array}{l}34 \text { individuals, } 68 \\
\text { alleles } \mathrm{n}(\%)\end{array}$ & & & \\
\hline \multicolumn{6}{|l|}{ DPB1 } \\
\hline *04:02 & $5(20.8)$ & $9(13.2)$ & 0.5752 & $1.72(0.51-5.78)$ & NS \\
\hline$\star 04: 01$ & $4(16.7)$ & $18(26.5)$ & 0.4904 & $0.55(0.17-1.85)$ & NS \\
\hline *17:01 & $3(12.5)$ & $2(2.9)$ & 0.2105 & $4.71(0.74-30.14)$ & NS \\
\hline *03:01 & $2(8.3)$ & $7(10.3)$ & 0.7810 & $0.79(0.15-4.11)$ & NS \\
\hline *16:01 & $2(8.3)$ & $1(1.5)$ & 0.3376 & $6.09(0.53-70.47)$ & NS \\
\hline \multicolumn{6}{|l|}{ Others } \\
\hline Both groups \# & $8(33.4)$ & $19(27.9)$ & NS $\S$ & & NS \\
\hline Control group $†$ & 0 & $12(17.7)$ & & & \\
\hline
\end{tabular}

Table 6. Frequency of HLA class II DQB1 alleles in NMOSD patients and healthy controls from southern Brazil.

\begin{tabular}{|c|c|c|c|c|c|}
\hline \multirow[b]{2}{*}{ Variable } & NMOSD & Controls & \multirow[b]{2}{*}{$\mathrm{p}$-value } & \multirow[b]{2}{*}{ OR $(95 \% \mathrm{Cl})$} & \multirow[b]{2}{*}{$p^{c}$} \\
\hline & $\begin{array}{l}12 \text { patients, } 24 \\
\text { alleles } \mathrm{n}(\%)\end{array}$ & $\begin{array}{c}150 \text { individuals } 300 \\
\text { alleles } \mathrm{n}(\%)\end{array}$ & & & \\
\hline \multicolumn{6}{|l|}{ DQB1 } \\
\hline *05:01 & $5(20.8)$ & $29(9.7)$ & 0.1702 & $2.46(0.85-7.08)$ & NS \\
\hline$\star 02: 01$ & $4(16.7)$ & $33(11.0)$ & 0.6126 & $1.62(0.52-5.02)$ & NS \\
\hline *03:01 & $2(8.3)$ & $56(18.7)$ & 0.3202 & $0.40(0.09-1.73)$ & NS \\
\hline *03:02 & $2(8.3)$ & $30(10.0)$ & 0.7923 & $0.82(0.18-3.65)$ & NS \\
\hline *03:19 & $2(8.3)$ & $5(1.7)$ & 0.1521 & $5.36(0.98-29.25)$ & NS \\
\hline$* 04: 02$ & $2(8.3)$ & $16(5.3)$ & 0.8773 & $1.61(0.34-7.47)$ & NS \\
\hline \multicolumn{6}{|l|}{ Others } \\
\hline Both groups \# & 7 (37.6) & $89(29.7)$ & NS $\S$ & & NS \\
\hline Control group $†$ & 0 & $42(13.9)$ & & & \\
\hline
\end{tabular}

HLA: human leukocyte antigen; NMOSD: neuromyelitis optica spectrum disorders; $p$ : value of $p$ using the chi-squared test with Yates' continuity correction; OR: odds ratio; $p^{c}$ : Probability after Bonferroni correction for 13 multiple comparisons for $p<0.05$; NS: Non-significant; \# At least one allele was found in both groups: *03:03, *05:02, *05:03, *06:02, *06:03, *06:04, *06:30; †: Alleles found only in controls (one or more), ${ }^{\star} 02: 02, * 03: 04,{ }^{*} 03: 19, * 06: 01, * 06: 09, * 16: 01 ; \S$ : statistical analysis was done comparing each allele individually.

( $\mathrm{p}=0.0005$; OR 13.89; 95\% CI 2.96-65.19) (Table 7). The difference in frequency of other alleles were not statistically significant when compared with the control group.

\section{DISCUSSION}

In NMO, the frequency of the HLA class I alleles has only rarely been described ${ }^{10}$. This is the first study to investigate the HLA class I alleles in Brazilian NMO patients by high-resolution methods. Our most frequent HLA class I alleles were $A^{*} 02: 01, A^{*} 24: 02, B^{*} 07: 02$ and $C^{*} 04: 01$. As the previously published data were collected using low-resolution techniques, we did not find any previous reports with sufficiently high-resolution methods to compare with our data ${ }^{10}$.

The allele $H L A-A{ }^{*} 24: 02$ was related to autoimmune type 1 diabetes, and more often found in optic neuritis patients and in primary Sjögren syndrome patients ${ }^{23,27,28,29}$. Our NMO patients with $H L A-A^{*} 24: 02$ did not present with any such diseases, except optic neuritis.

The alleles $H L A-B^{*} 07: 02$ and $H L A-C^{*} 04: 01$ were the most frequent alleles in our NMO patients, as well as in the control population.

The frequencies of some HLA class II alleles were similar to the previous profiles described in European populations ${ }^{10,14,25}$.

In our patients, the HLA class II DPB1*04:01, *04:02 and *17:01 alleles were the more frequent, but the differences in their frequencies were not significant compared with the control population. The frequency of allele $D P B 1^{*} 04: 01$ was similar to that obtained in French Caucasian patients and in

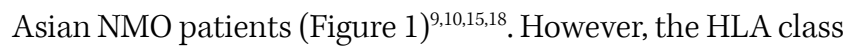
II DPB1*05:01 allele showed a somewhat higher frequency in

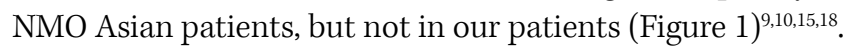
In addition, although the allele $D P B 1 * 01: 01$ was previously 
Table 7. Frequency of HLA class II DRB1 alleles in NMOSD patients and healthy controls from southern Brazil.

\begin{tabular}{|c|c|c|c|c|c|}
\hline \multirow[b]{2}{*}{ Variable } & NMOSD & Controls & \multirow[b]{2}{*}{$\mathrm{p}$-value } & \multirow[b]{2}{*}{ OR (95\% Cl) } & \multirow[b]{2}{*}{$\mathrm{p}^{\mathrm{c}}$} \\
\hline & $\begin{array}{c}15 \text { patients, } 30 \\
\text { alleles } \mathrm{n}(\%)\end{array}$ & $\begin{array}{c}252 \text { individuals, } 504 \\
\text { alleles } n(\%)\end{array}$ & & & \\
\hline \multicolumn{6}{|l|}{ DRB1 } \\
\hline *03:01 & $5(16.7)$ & $28(5.6)$ & 0.389 & $3.4(1.21-9.55)$ & NS \\
\hline$\star 04: 05$ & $3(10.0)$ & $2(0.4)$ & $<0.0001$ & $27.89(4.47-173.97)$ & 0.0016 \\
\hline$\star 10: 01$ & $3(10.0)$ & $22(4.4)$ & 0.3298 & $2.43(0.69-8.64)$ & NS \\
\hline *16:02 & $3(10.0)$ & $4(0.8)$ & 0.0005 & $13.89(2.96-65.19)$ & 0.0085 \\
\hline$\star 01: 01$ & $2(6.7)$ & $20(4.0)$ & 0.8028 & $1.72(0.38-7.77)$ & NS \\
\hline$* 07: 01$ & $2(6.7)$ & $88(17.5)$ & 0.1994 & $0.34(0.08-1.44)$ & NS \\
\hline *13:02 & $2(6.7)$ & $15(3.0)$ & 0.5597 & $2.33(0.51-10.69)$ & NS \\
\hline \multicolumn{6}{|l|}{ Others } \\
\hline Both groups \# & $10(33.2)$ & $194(38.6)$ & $N S \S$ & & NS \\
\hline Control group † & 0 & $131(25.7)$ & & & \\
\hline
\end{tabular}

reported as having increased susceptibility to NMO in a French population, this allele was not statistical significant in our study, as well as not found in an Asian population (Figure 1) ${ }^{9,10,15,18}$. The HLA-DPB1*02:02, *15:01, *46:01 and *100:01 alleles occurred only in our NMO patients and this requires further investigation in other populations to confirm their real influence on the NMO susceptibility.

The HLA class II alleles $D Q B 1^{*} 02: 01$ and $D Q B 1^{*} 05: 01$ showed higher frequencies in our patients, but these differences were not statistically significant compared with our control population. Similar findings were described in the French, Muslim Arabs in Israel, and southeastern Brazilian patients (Figure 2) ${ }^{10,20,21}$. The $H L A-D Q B 1^{*} 06: 30$ allele was found in one NMO patient, but not in the controls, and this discovery may suggest an increased susceptibility to the disease. In French Afro-Caribbean patients, the allele $D Q B 1^{*} 06$ was statistically correlated with multiple sclerosis but not with NMO patients ${ }^{16}$.

In our patients, the $D R B 1^{*} 03: 01$ was more frequent than in the control group, which was similar to the southeastern Brazilian, Chinese and Japanese studies but different to the Muslim Arabs in Israel study (Figure 3) 9,15,18,20,21,22. The difference in frequency of the $D R B 1^{*} 04: 05$ allele showed a positive correlation (increased susceptibility) in our study; however, previous studies in Asian populations revealed a negative correlation (decreased susceptibility) in NMO patients (Figure 3) $)^{9,15,18,20}$. This same allele was associated with other autoimmune diseases in Asian populations ${ }^{30,31}$. In addition, a positive relationship of the allele $* 16: 02$ was found in our study, which was similar to others studies in Asian populations (Figure 3) $)^{9,15,18}$. We did not find any NMO patients with allele ${ }^{*} 15: 01$, which is quite common in multiple sclerosis and frequent in our population ${ }^{22,32}$.

To date, there have been only three studies performed with Brazilian patients, who had a different ethnic background when compared with southern Brazil because the recruited patients were from southeastern Brazil ${ }^{11,12,21}$. The first Brazilian study showed that the most frequent HLA class II allele was the $D R B 1^{*} 03$ allele in mulatto-designated NMO patients ${ }^{11}$. This allele frequency was similar to our study, but when compared with the control group from southern Brazil, the difference was not statistically significant. In the second Brazilian study, which was carried out in Afro-descendent and Caucasian patients, no association was found between NMO and the extended haplotype $D R B 1 * 15: 01-D Q A 1 * 01: 02-$ $D Q B 1^{*} 06: 02$ or their alleles ${ }^{12}$. The third Brazilian study was the most recent, which showed similar findings of the allele $D R B 1^{*}$ 03:01 to our NMO patients from southern Brazil ${ }^{21}$.

In our study, the small sample size influences the analysis of some HLA profiles, which was a limitation in this study. Additionally, we could speculate that the small size of our cohort, which was aggravated by the exclusion of some patients with an ambiguous genotype that was not suitable for statistical analysis, influenced the distribution of the HLA genotype. However, our findings confirmed that the southern Brazilian population has a different ethnic background than southeastern Brazilian populations.

In conclusion, our study suggested a different ethnic background of NMO in southern Brazilian patients than in other Brazilian populations. Currently, the southern Brazilian population has a multi-ethnic nature and their HLA profile may be different from the original European descedants. In our NMO patients, an European profile was expected, but the HLA genotyping resembled European and Asian populations, revealing the current mixing of the HLA profile of the southern Brazilian population. In addition, some new HLA genotypes were associated with increased susceptibility to NMO in our patients, particularly for some HLA class I and HLA-DRB1*04:05 and *16:02. 

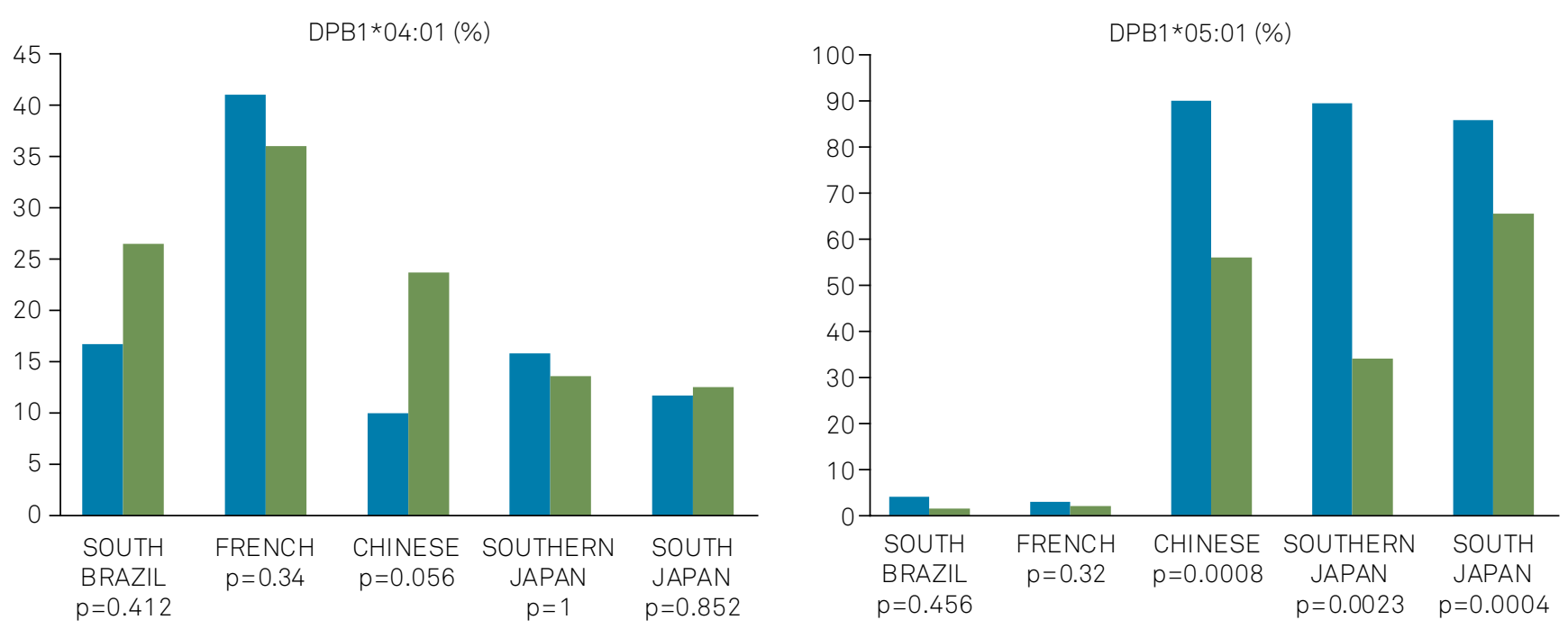

DPB1*01:01 (\%)

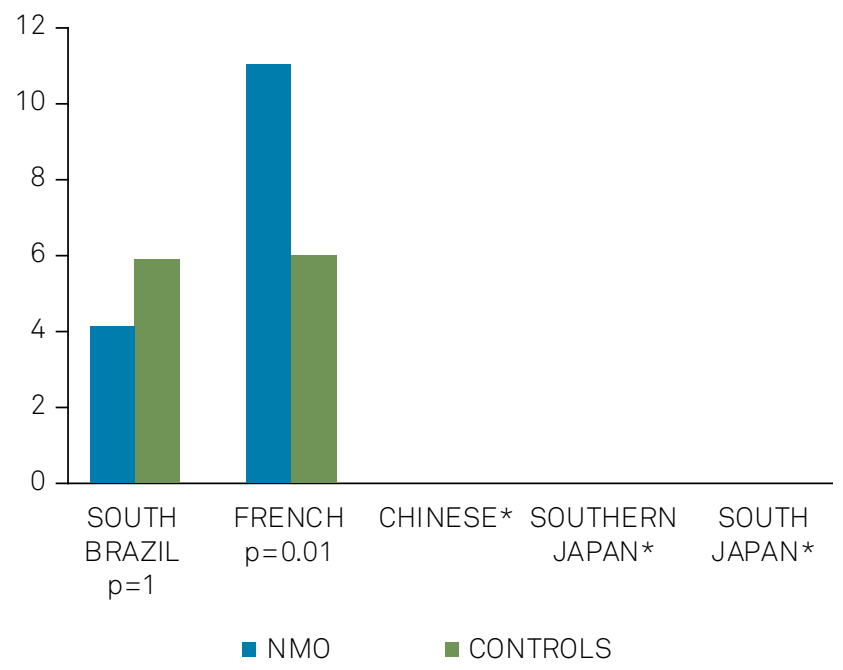

Figure 1. The frequency of *04:01, *05:01 and *01:01 alleles of the HLA-DPB1 comparing southern Brazil (present study), French ${ }^{10}$, China ${ }^{15}$, southern Japan ${ }^{9}$ and south Japan ${ }^{18}$ populations. \#: allele was not found in patients or controls of this study.
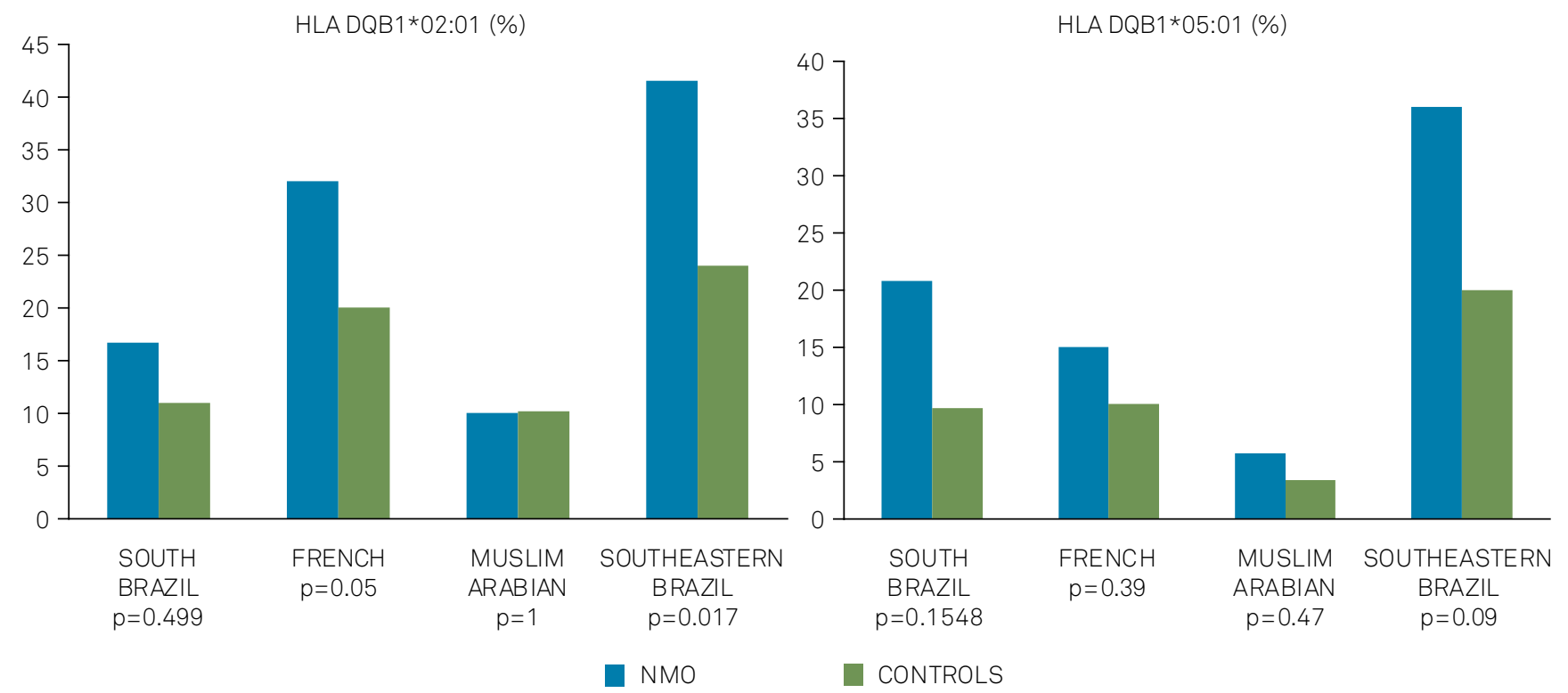

Figure 2. The frequency of *02:01 and *05:01 alleles of the HLA-DQB1 comparing southern Brazil (present study), French¹0, China ${ }^{15}$, Muslim Arabian (Israel) ${ }^{20}$ and southeastern Brazil ${ }^{21}$ populations. 

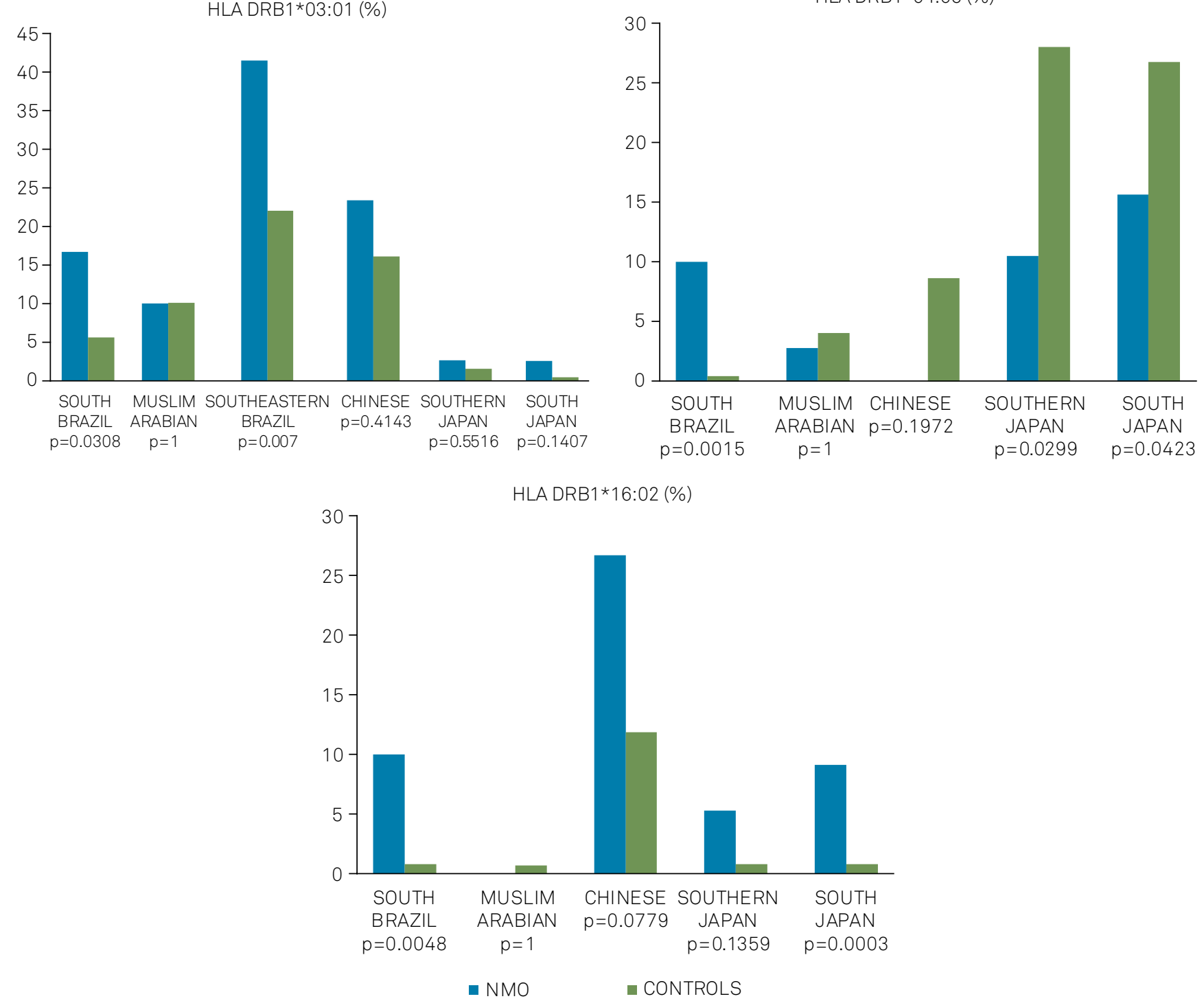

Figure 3. The frequency of *03:01, *04:05 and *16:02 alleles of the HLA-DRB1 comparing southern Brazil (present study), Muslim Arabian (Israel) ${ }^{20}$, southeastern Brazil ${ }^{21}$, China ${ }^{15}$, southern Japan ${ }^{9}$ and south Japan ${ }^{18}$ populations.

\section{Acknowledgments}

The authors thank Noemi Farah Pereira, BSc, PhD, and the Immunogenetics Laboratory staff of Hospital de Clínicas, Universidade Federal do Paraná, Curitiba, PR, Brazil, for allowing the use of the control group data. The study was supported by the Conselho Nacional de Desenvolvimento Científico e Tecnológico (CNPq) and Universidade Federal do Paraná (UFPR). Prof. L. C. Werneck received a productivity grant $1 \mathrm{~A}$ from CNPq.

\section{References}

1. Lennon VA, Wingerchuk DM, Kryzer TJ, Pittock SJ,

Lucchinetti CF, Fujihara K, et al. A serum autoantibody

marker of neuromyelitis optica: distinction from

multiple sclerosis. Lancet. 2004 Dec;364(9451):2106-12.

https://doi.org/10.1016/S0140-6736(04)17551-X

2. Fujihara K. Neuromyelitis optica and astrocytic damage in its pathogenesis. J Neurol Sci. 2011 Jul;306(1-2):183-7. https://doi.org/10.1016/j.jns.2011.02.018

3. Misu T, Höftberger R, Fujihara K, Wimmer I, Takai Y, Nishiyama S, et al. Presence of six different lesion types suggests diverse mechanisms of tissue injury in neuromyelitis optica. Acta Neuropathol. 2013 Jun;125(6):815-27. https://doi.org/10.1007/s00401-013-1116-7

4. Trowsdale J, Knight JC. Major histocompatibility complex genomics and human disease. Annu Rev Genomics Hum Genet. 2013;14(1):301-23. https://doi.org/10.1146/annurev-genom-091212-153455

5. Gough SC, Simmonds MJ. The HLA region and autoimmune disease: associations and mechanisms of action. Curr Genomics. 2007 Nov;8(7):453-65. https://doi.org/10.2174/138920207783591690

6. Sachs JA. HLA antigens in multiple sclerosis. Proc R Soc Med. 1977 Dec;70(12):869-71. 
7. Yamasaki K, Horiuchi I, Minohara M, Kawano Y, Ohyagi Y, Yamada T, et al. HLA-DPB1*0501-associated opticospinal multiple sclerosis: clinical, neuroimaging and immunogenetic studies. Brain. 1999 Sep;122(Pt 9):1689-96. https://doi.org/10.1093/brain/122.9.1689

8. Cabrera-Gómez JA, Ramón-Pérez L, Saiz A, Llerena-Fernández P, Fernández-Fernández L, Ercilla G, et al. Neuromyelitis optica and multiple sclerosis in sisters. Mult Scler. 2009 Feb;15(2):269-71. https://doi.org/10.1177/1352458508097921

9. Matsushita T, Matsuoka T, Isobe N, Kawano Y, Minohara M, Shi N, et al. Association of the HLA-DPB1*0501 allele with anti-aquaporin-4 antibody positivity in Japanese patients with idiopathic central nervous system demyelinating disorders. Tissue Antigens. 2009 Feb;73(2):171-6. https://doi.org/10.1111/j.1399-0039.2008.01172.x

10. Zéphir H, Fajardy I, Outteryck O, Blanc F, Roger N, Fleury $M$, et al. Is neuromyelitis optica associated with human leukocyte antigen? Mult Scler. 2009 May;15(5):571-9. https://doi.org/10.1177/1352458508102085

11. Brum DG, Barreira AA, Santos AC, Kaimen-Maciel DR, Matiello M, Costa RM, et al. HLA-DRB association in neuromyelitis optica is different from that observed in multiple sclerosis. Mult Scler. 2010 Jan;16(1):21-9. https://doi.org/10.1177/1352458509350741

12. Papais-Alvarenga M, Papais-Alvarenga RM, Papais-Alvarenga M, Cruz GS, Vasconcelos CC, Pinto-Medel MJ, et al. Relapsing neuromyelitis optica is not associated with the HLA DR2 haplotype in a Brazilian cohort from Rio de Janeiro. Mult Scler. 2010;16:S79-80.

13. Tanaka Y, Yoshikura N, Harada N, Yamada M, Koumura A, Sakurai T, et al. Neuromyelitis optica in Japanese sisters. Intern Med. 2011;50(22):2829-32. https://doi.org/10.2169/internalmedicine.50.5613

14. Blanco Y, Ercilla-González G, Llufriu S, Casanova-Estruch B, Magraner MJ, Ramió-Torrentá L, et al. [HLA-DRB1 typing in Caucasians patients with neuromyelitis optica]. Rev Neurol. 2011 Aug;53(3):146-52. Spanish.

15. Wang H, Dai Y, Qiu W, Zhong X, Wu A, Wang Y, et al. HLA-DPB1 0501 is associated with susceptibility to anti-aquaporin-4 antibodies positive neuromyelitis optica in southern Han Chinese. J Neuroimmunol. 2011 Apr;233(1-2):181-4 https://doi.org/10.1016/j.jneuroim.2010.11.004

16. Deschamps R, Paturel L, Jeannin S, Chausson N, Olindo S, Béra O, et al. Different HLA class II (DRB1 and DQB1) alleles determine either susceptibility or resistance to $\mathrm{NMO}$ and multiple sclerosis among the French Afro-Caribbean population. Mult Scler. 2011 Jan;17(1):24-31. https://doi.org/10.1177/1352458510382810

17. Asgari N, Nielsen C, Stenager E, Kyvik KO, Lillevang ST. HLA, PTPN22 and PD-1 associations as markers of autoimmunity in neuromyelitis optica. Mult Scler. 2012 Jan;18(1):23-30. https://doi.org/10.1177/1352458511417480

18. Yoshimura S, Isobe N, Matsushita T, Yonekawa T, Masaki K, Sato $S$, et al. Distinct genetic and infectious profiles in Japanese neuromyelitis optica patients according to anti-aquaporin 4 antibody status.J Neurol Neurosurg Psychiatry. 2013 Jan;84(1):29-34. https://doi.org/10.1136/jnnp-2012-302925

19. Pandit L, Malli C, D'Cunha A, Mustafa S. Human leukocyte antigen association with neuromyelitis optica in a south Indian population. Mult Scler. 2015 Aug;21(9):1217-8. https://doi.org/10.1177/1352458515574149
20. Brill L, Mandel M, Karussis D, Petrou P, Miller K, Ben-Hur T, et al. Increased occurrence of anti-AQP4 seropositivity and unique HLA Class II associations with neuromyelitis optica (NMO), among Muslim Arabs in Israel.J Neuroimmunol. 2016 Apr;293:65-70. https://doi.org/10.1016/j.jneuroim.2016.02.006

21. Alvarenga MP, Fernandez O, Leyva L, Campanella L, Vasconcelos $\mathrm{CF}$, Alvarenga $\mathrm{M}$, et al. The HLA DRB1*03:01 allele is associated with $\mathrm{NMO}$ regardless of the NMO-IgG status in Brazilian patients from Rio de Janeiro. J Neuroimmunol. 2017 Sep;310:1-7. https://doi.org/10.1016/j.jneuroim.2017.05.018

22. Estrada K, Whelan CW, Zhao F, Bronson P, Handsaker RE, Sun $\mathrm{C}$, et al. A whole-genome sequence study identifies genetic risk factors for neuromyelitis optica. Nat Commun. 2018 May;9(1):1929. https://doi.org/10.1038/s41467-018-04332-3

23. Matiello M, Schaefer-Klein J, Brum DG, Atkinson EJ, Kantarci OH, Weinshenker BG. HLA-DRB1*1501 tagging rs3135388 polymorphism is not associated with neuromyelitis optica. Mult Scler. 2010 Aug;16(8):981-4. https://doi.org/10.1177/1352458510374340

24. Wingerchuk DM, Lennon VA, Pittock SJ, Lucchinetti CF, Weinshenker BG. Revised diagnostic criteria for neuromyelitis optica. Neurology. 2006 May;66(10):1485-9. https://doi.org/10.1212/01.wnl.0000216139.44259.74

25. Wingerchuk DM, Lennon VA, Lucchinetti CF, Pittock SJ, Weinshenker BG. The spectrum of neuromyelitis optica. Lancet Neurol. 2007 Sep;6(9):805-15. https://doi.org/10.1016/S1474-4422(07)70216-8

26. Lana-Peixoto MA, Callegaro D. The expanded spectrum of neuromyelitis optica: evidences for a new definition. Arq Neuropsiquiatr. 2012 Oct;70(10):807-13. https://doi.org/10.1590/S0004-282X2012001000010

27. Mbunwe E, Van der Auwera BJ, Vermeulen I, Demeester S, Van Dalem A, Balti EV, et al.; Belgian Diabetes Registry. $H L A-A * 24$ is an independent predictor of 5-year progression to diabetes in autoantibody-positive first-degree relatives of type 1 diabetic patients. Diabetes. 2013 Apr;62(4):1345-50. https://doi.org/10.2337/db12-0747

28. Amirzargar AA, Tabasi A, Khosravi F, Kheradvar A, Rezaei $\mathrm{N}$, Naroueynejad M, et al. Optic neuritis, multiple sclerosis and human leukocyte antigen: results of a 4-year follow-up study. Eur J Neurol. 2005 Jan;12(1):25-30. https://doi.org/10.1111/j.1468-1331.2004.00901.x

29. Loiseau P, Lepage V, Djelal F, Busson M, Tamouza R, Raffoux C, et al. HLA class I and class II are both associated with the genetic predisposition to primary Sjögren syndrome. Hum Immunol. 2001 Jul;62(7):725-31. https://doi.org/10.1016/S0198-8859(01)00253-1

30. Nakamura Y, Matsushita T, Sato S, Niino M, Fukazawa T, Yoshimura S, et al. Latitude and HLA-DRB1*04:05 independently influence disease severity in Japanese multiple sclerosis: a cross-sectional study. J Neuroinflammation. 2016 Sep;13(1):239. https://doi.org/10.1186/s12974-016-0695-3

31. Yanagimachi M, Miyamae T, Naruto T, et al. Association of HLA-A*02:06 and HLA-DRB1*04:05 with clinical subtypes of juvenile idiopathic arthritis. J Hum Genet 2011;56:196-199.

32. Oksenberg JR, Barcellos LF, Cree BA, Baranzini SE, Bugawan TL, Khan O, et al. Mapping multiple sclerosis susceptibility to the HLA-DR locus in African Americans. Am J Hum Genet. 2004 Jan;74(1):160-7. https://doi.org/10.1086/380997 